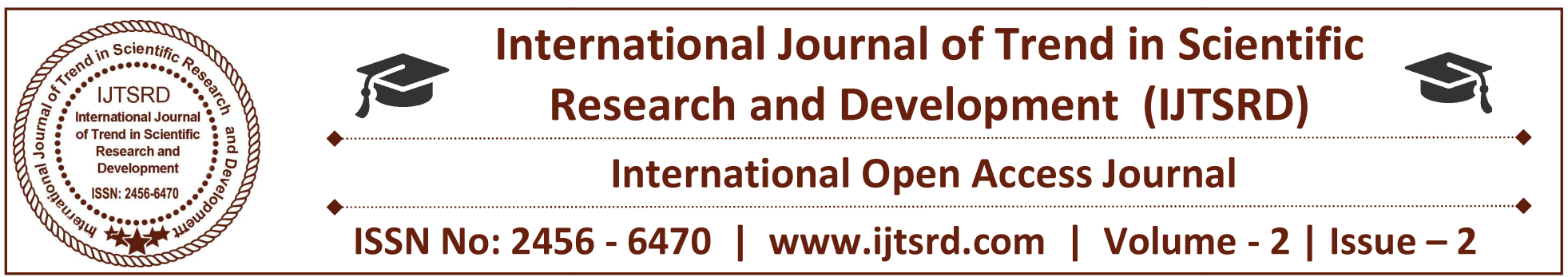

\title{
Effects of English on Pattern of Education System in India
}

\author{
SK Habib \\ Assistant Teacher, Dasbaga Basu Kacharibati Primary School, \\ Uluberia East, Howrah, West Bengal, India
}

\begin{abstract}
\end{abstract}
This Study deals with the impact of the English and the changing example of the instructive framework. For a comprehension of the improvement of the western instruction in India, exertion must be made to touch the recorded angles keeping in mind the end goal to make the review less demanding. The East India Company which came to India in 1600 AD scarcely gave any regard for the Indian instruction. Since it was basically worried with the advancement of business interests, it was not anticipated that of them would make any genuine strides for the instruction of the general population of India. The English were credited for changing the scholarly existence of India through the presentation of a Western System of Education in the subcontinent. The English arrangement of current training and the western thoughts assumed a critical part really taking shape of the social and instructive history of India. R.C. Majumdar states: If we need to pick one single variable which helped more than others in realizing the considerable change in India in the nineteenth century, we can with no delay indicate the English advanced education.

Keywords: Effects, English Pattern, Education System, India, development, western education, people, higher education, etc.

\section{Introduction}

In the beginning of the nineteenth century itself the Protestant missionaries started working in Travancore and Cochin. Among them Ringeltaube, the Prussian missionary started his educational activities in 1806 itself. He established educational institutions and propagated Christianity and education simultaneously. For the first sixty years of its dominion in India the East India Company - a trading, profit making concern took little interest in the education of its subjects. Exception should be given to the work done by missionaries in the field of education, because the missionaries got certain financial grants from the company. There were, however, two very minor exceptions to this policy. At the time of the arrival of the British, Kerala was divided mainly into three political units, the princely states of Travancore and educational process in Kerala initiated efficiently with the appearance of the British. Their political and managerial exercises likewise directly affected the training of the masses. Training perpetually mirrors the thoughts of the general public. With each adjustment in the sociopolitical design, the association and destinations of training additionally, ordinarily changes. So in the structure, substance and strategy for the entire arrangement of instruction in India had some ensuing changes. The East India Company till 1813 scarcely had any enthusiasm for the field of instruction. Be that as it may, in the second $50 \%$ of the eighteenth century evangelists opened vernacular schools to spread Christianity among the poor segments of the populace. This was an eye-opener to the organization, and numerous improvements that occurred in India thusly reinforced the position of the organization. Before long the organization turned out to be politically capable and its instructive arrangement likewise experienced a tremendous change [1-5]. Prior the organization had confined its consideration just to the training of European and 
Anglo-Indian youngsters. There existed mission stations at Serampore outstations of the Baptists of Dinajpur; in the Indigo locale where Carey had worked before settling in Serampore; and at Jessore, the very much watered delta areas of Eastern Bengal. The London Missionary Society was occupied in Dutch Chinsurah and at Vizagapatanam. In Madras and Tamil nation no new work was jumped up nearby that of the veteren fathers of the Danish Mission. In the Kanarese nation there was just the singular station of Bellary, and that had been established in 1812. In Bombay the primary teachers of a non-English society, the American Board, had after incredible uneasiness recently figured out how to get a dependable balance. As its energy developed, the East India Company turned out to be increasingly worried about the mollification of local elites and took after an approach of non-obstruction in social and religious matters. In addition, the Company expected that the western instruction would make it lose its provinces, as it had done in America. In the field of instruction the administration immovably received the orientalist approach putting aside the work of the ministers in schools which were led in the medium of English dialect with an accentuation on evangelism [6-8]. The purpose for this strategy was that the organization even liked to consume cash for the insurance of its regions, instead of gambling it for instructive cum preacher exercises.

\section{Review of Literature}

During the first half of the nineteenth century the obligation of conferring instruction lay basically in the hands of the conventional indigenous foundations and the teachers. The evangelists dedicated a greater amount of their thoughtfulness regarding spread English instruction while they disregarded in their schools educating of Malayalam and Sanskrit. The contract of the East India Company came up for the typical restoration in 1833. A Parliament Committee looked into the working of the organization's framework and set down new standards of enactment prompting the Act of 1833. At the point when the Charter of the East India Company was reestablished in $1833 /$ the sum requested to be spent on training was likewise improved from one lakh to ten lakh rupees. This sanction besides requested that the organization be more tolerant towards teachers which brought about their more prominent association in training [912]. The subject of using the new assignments for training afresh brought on a contention. This swung to be one of the drawn out and astringent debates of the nineteenth century. There were offers from the Indian pioneers like Raja Ram Mohan Roy and Radhakant Dev who compelled the legislature for another instructive strategy. In 1834 the Government of India designated a Board of Education which was an extraordinary stride towards the possible development of an instructive strategy. Thomas Babington Macaulay (a while later Lord Macaulay), the outstanding student of history and researcher, came to India on tenth June 1834 as a Law Member of the Governor's Executive Council. He assumed control over the Presidency of the Board in 1834 when an astringent discussion was going ahead between the Orientalists and Anglicists about the recently distributed allow by the East India Company for training. Ruler William Bentick, the then Governor General, delegated Lord Macaulay as the Chairman of the Board of Education Commission for detailing about the circumstances and how it could be moved forward. The celebrated Minutes of Lord Macaulay was submitted on second February 1835 to the then Governor General William Bentick. This was supported on seventh March and it set down fit as a fiddle an instructive strategy for the British to take after $\mathrm{m}$ India. A determination association was to the accompanying impact, "The immense protest of the British Government should be the advancement of European writing and sciences among the locals of India, and that every one of the assets appropriated with the end goal of instruction would be best utilized on English training alone". He additionally proposed to use add up to instructive give to accomplish that objective and to utilize the current foundations of oriental learning for the advancement of western instruction. The arrangement was generally acknowledged and it turned into an establishment stone for present day Indian training. Along these lines, K.M. Panickar, the acclaimed history specialist, called Macaulay as one of the three Englishmen to be recollected' for the commitment made to the reason for English instruction in India.

\section{Macaulay's Minutes issued the decree containing the accompanying.}

1. The main target of this instructive approach is to support European knowledge.

2. That no more stipends will be given to students pursuing oriental out of date studies.

3. That the legislature won't allow oriental books.

4. That the assets hence accessible will be utilized in advancement of European reviews and English language. 
Ruler Macaulay additionally made it clear in his own words: We are allowed to utilize our assets as we choose. It is conceivable to make locals of these nation altogether great English researchers. To this end, our endeavors should be coordinated. At last the discussions finished that may some way or another have delayed for a considerable length of time. From now on English dialect and western science began accepting expanded significance in current advanced education in India. It was acknowledged by the English that for them interior advance was more important than protection of the indigenous social values in India. The opening of an English School in 1834 at state cost was especially noteworthy on the grounds that it was around the same time Macaulay was selected to write about the practicality or generally of presenting English Education in India. The announcement on seventh March 1835 of Lord Bentick provided for the instructive strategy of the English in India a distinct frame, clear vision and a recognized plan. In Travancore additionally state support to training took fluctuated shapes. One was that of the stipends and liberal recompenses to understudies and educators. In 1835, His Highness enriched twenty free grants to Nair understudies in the English school and manufactured another house for it. In that year, the English school at Trivandrum was assumed control by the administration and given the title 'The Raja Free School'. This chief instructive establishment later created into His Highness the Maharajas' College.

The Proclamation made in 1844 by Governor Lord Hardinge, expressing that inclination ought to be given in the determination of possibility for open work to those who had been instructed in the organizations built up by the English, gave advance driving force to English Education in India. In 1844, the Maharaja of Travancore made a comparable decree in the matter of open administration that inclination would be given to the individuals who were knowledgeable in English gave a further lift to English instruction. In Cochin too an endeavor was made in 1835, that year in which the celebrated Macaulay's Minutes, with a view to instructing the Jews English, Hebrew and Malayalam. Later in 1837 and 1845 two English schools were opened with a view to instructing the sovereigns and the offspring of the privileged. One of these schools later formed into Maharaja's College. The History of Malabar area amid the nineteenth century was one of developing social and mutual turmoil and expanding ill will between the Muslims populace and the British. Thus, nearly little advance took put in the field of training in Malabar. A couple of English Secondary Schools and universities were set up in congruity with the strategy followed in whatever is left of India in compatibility of the circumstances proposed by the Minutes of Macaulay. The Woods Dispatch and its Effects the year 1854 denoted a huge age ever, for it saw the presence of a Dispatch which laid out an orderly instructive strategy for India. The from the grade school to the University level Woods Dispatch of 1854 has properly been depicted as the Magna Carta of English training in India and the cornerstone of India's available framework and structure of instruction [13-15]. The targets of the Dispatch were for the most part four as referred to by Anima Bose in 'Advanced education in India in the Nineteenth Century'. Right off the bat, to present upon the general population of India the good and material gifts which spill out of the dissemination of helpful information and which may get from India's association with the English? Besides, to help the general population of India with work and capital, and furthermore to help them to imitate the British in the improvement of the immense assets of the nation. Thirdly, to empower Britain to secure an extensive and more supply of articles vital for the British producers and British purchasers. This would keep the British workers very much provided with crude materials. Fourthly, to diffuse the enhanced expressions, sciences, theory and writing of Europe and to spread European learning in the topic of the medium of guideline was additionally managed in the Dispatch. The Dispatch expelled the possibility that English was to be utilized as a medium of guideline keeping in mind the end goal to smother or to dishearten the investigation of Indian dialects. Rather, the Dispatch demonstrated a model to whatever is left of the world how English and the Indian dialects could together help in spreading training all through India. It obviously expressed that English ought to be utilized just in higher branches of learning and the vernacular to instruct the mass that were uninformed of English. The following plan was the foundation of evaluated schools all over India. At top were the college and associated universities which gave direction in different branches of expressions and science. Beneath the colleges came the secondary schools that were required to give direction either through English or through one of the advanced Indian dialects; and, at the base came the indigenous elementary schools. The Dispatch in a way dismisses 'Descending Filtration Theory', and embraced Indian 
dialects at secondary school level. The setting up of indigenous schools established solid frameworks for a national arrangement of training. It ought to be conceded that in its initial days in India, the British Raj did just next to no to promote the reason for training. Be that as it may, there was a steady advance towards arranging an instructive motivation for India. 3. Current Status of English as a Medium in Education Language arranging game plans for school training in India can be viewed as additional to be an issue of status masterminding as opposed to acquiring orchestrating. The lingo talk in training in the formative years of India's flexibility not quite recently obtained care among the accomplices of direction, it similarly enabled the course of action makers to totally attempt to comprehend the built up vision of value of shot, semantic benefits of each phonetic and ethnic gathering and moving towards the goal of finishing general access to instruction. English even today continues going about as a key "Association" lingo. English symbolizes in Indian identities better direction, better culture and better mind. It is still energetically used as a piece of association, legitimate, in direction and despite for unique purposes in India. English now has transformed into the hugest dialect in India. English, the dialect constrained in the midst of British Raj has significantly settled in India, and now has for all intents and purposes advanced toward turning into an indispensable piece of our regular day to day existence. This tongue is not learnt and used now-adays out of any burden however through the affirmation that it has certain unavoidable positive conditions. Today the driving forces of learning English are no longer essentially political yet intelligent and mechanical. The immense push for English started with India's claim that it had an English-tongue advantage that would make it a primary "learning economy" and the delinquent exposure, as lowend advantage division livelihoods in call centers and BPOs went an asking, that in truth this was not the circumstance. The smart settle game plan that has transformed into a sort of mantra is that English is the principle way out. It will close the capacities gap, offer business openings and set the country on its approach to hugeness. This stupid association between openings for work, money related accomplishment and the English tongue has a growing number of urban basic workers and lower salaried class watchmen putting hard-earned trade out private English-medium mentoring, as often as possible of unverifiable quality. Today, pretty much a fourth of every single Indian child go to educational cost based schools, a basic degree of them legitimately English-medium. It is this move has made a couple states like Tamil Nadu and Maharashtra offer an English-medium option in existing government schools in the desire of stemming the surge of understudies out of state schools to educational cost based schools.

\section{Conclusion}

In India, the raw difference in income between individuals who communicate in English and individuals who don't is huge, yet this exaggerates the monetary estimation of English in light of the fact that higher capacity individuals will probably be capable in English In this paper, we exploit a rich informational collection to moderate this capacity predisposition. In the wake of controlling for age, social gathering, tutoring, topography and intermediaries for capacity, we find that there are expansive, factually critical comes back to English dialect abilities in India. Time-based compensations are by and large $34 \%$ higher for men who talk familiar English and 13\% higher for men who talk somewhat English in respect to men who talk no English. For ladies, the normal returns are $22 \%$ for familiar English and $10 \%$ for somewhat English. There is extensive heterogeneity in the profits to English. More experienced and more instructed specialists get higher comes back to English. The complementarily between English aptitudes and instruction seems to have reinforced over time- only the more taught among youthful laborers win a premium for English ability, though more seasoned specialists over all training bunches do. In India and numerous other creating nations, there is dynamic civil argument about whether to advance the nearby dialect or an all the more all inclusive acknowledged dialect like English in schools.

\section{References:}

1. Government of India 2007. Selected Educational Statistics 2004-05. New Delhi: Ministry of Human Resource Development, Statistics Division.

2. Afridi, F. (2010), - The Impact of School Meals on School Participation: Evidence from Rural Indiall, Indian Statistical Institute Discussion Papers, No. 10-02.

3. Agarwal, P. (2009), Indian Higher Education, Envisioning the Future, Sage, New Delhi. 
4. Aghion, P., M. Dewatripont, C. Hoxby, A. MasColell and A. Sapir (2010), - The Governance and Performance of Universities: Evidence from Europe and the US\|, Economic Policy, Vol. 25, No. 61.

5. Altbach, P. (2009), - The Giants Awake: The Present and Future of Higher Education Systems in China and Indiall, in OECD, Higher Education to 2030, Volume 2: Globalisation, OECD, Paris.

6. Altinok, N. and G. Kingdon (2009), -New Evidence on Class Size Effects: A Pupil Fixed Effects Approachll, CSAE Working Papers, No. 2009-16.

7. ASER (2010), Annual Status of Education Report (Rural) 2009, Pratham Resource Centre, Mumbai.

8. ASER (2011), Annual Status of Education Report (Rural) 2010, Provisional, Pratham Resource Centre, Mumbai.

9. Atherton, P. and G. Kingdon (2010), -The Relative Effectiveness and Costs of Contract and Regular Teachers in Indiall, CSAE Working Papers, No. 2010-15.

10. Azam, M., A. Chin and N. Prakash (2010), - The Returns to English Language Skills in Indiall, CReAM Discussion Papers, No. 02-10, University College London.
11. Banerjee, A.V., S. Cole, E. Duflo and L. Linden (2007), - Remedying Education: Evidence from Two Randomized Experiments in Indiall, Quarterly Journal of Economics, Vol. 122, No. 3.

12. Banerjee, A.V., R. Banerji, E. Duflo, R. Glennerster and S. Khemani (2010), -Pitfalls of Participatory Programs: Evidence from a Randomized Evaluation in Indiall, American Economic Journal: EconomicPolicy, Vol. 2, No. 1.

13. Banerji, R. and A. Mukherjee (2008), -Achieving Universal Elementary Education in India: Future Strategies for Ensuring Access, Quality and Financell, Journal of Applied Economic Research, Vol. 2, No. 2.

14. Bellei, Cristian. 2008. The PrivatePublic School Controversy: The Case of Chile. In School Choice International: Exploiting Public-Private Partnerships, edited by R. Chakrabarti and P. Petersen. Cambridge, Mass.: MIT Press.

15. Chakrabarti, Rajashri, and Paul Petersen, eds. 2008. School Choice International: Exploiting Public-Private Partnerships. Cambridge, Mass.: MIT Press. 